\title{
Genetic Diversity and Relationship of Ethiopian Potato Varieties to Germplasm from North America, Europe and the International Potato Center
}

\author{
Semagn Asredie Kolech ${ }^{1,2} \cdot$ Donald Halseth $^{1} \cdot$ Keith Perry $^{1} \cdot$ David Wolfe $^{1}$. \\ David S. Douches ${ }^{3}$ • Joseph Coombs ${ }^{3}$ • Walter De Jong ${ }^{1}$ (ID)
}

Published online: 20 October 2016

(C) The Author(s) 2016

\begin{abstract}
Potato is an increasingly important crop in Ethiopia, but the origin of local cultivars grown throughout the country is unknown. To evaluate the genetic diversity of Ethiopian potato cultivars, and to assess their relationship with germplasm from North America, Europe and the International Potato Center (CIP), 8303 SNP markers were used to characterize 44 local Ethiopian cultivars, as well as 26 CIP, 22 American and 17 European potato cultivars and advanced breeding clones. The marker data revealed that most of the local cultivars were duplicates; among the 44 cultivars tested, only 15 unique genotypes were observed. Principal component and neighborjoining dendrogram analyses showed that American, European and CIP germplasm form three distinct clusters, with older Ethiopian cultivars overlapping the European cultivars, suggesting that the oldest local cultivars are of European descent. Local cultivars overall separated into two distinct clusters, suggesting that at least two distinct introductions gave rise to current local cultivars in Ethiopia. Ethiopian germplasm harbors comparable levels of genetic diversity to American, European, and CIP germplasm and could provide the foundation for a national potato breeding program.
\end{abstract}

Resumen La papa es un cultivo con importancia en aumento en Etiopía, pero se desconoce el origen de las variedades

Walter De Jong

wsd2@cornell.edu

1 School of Integrative Plant Science, Cornell University, Ithaca, NY 14853, USA

2 Amhara Regional Agricultural Research Institute (ARARI), Bahir Dar, Ethiopia

3 Department of Plant, Soil and Microbial Sciences, Michigan State University, East Lansing, MI 48824, USA locales cultivadas a lo largo del País. Para evaluar la diversidad genética de las variedades de papa de Etiopía, y para analizar su relación con germoplasma de Norteamérica, Europa y el Centro Internacional de la Papa (CIP), se usaron 8303 marcadores SNP para caracterizar 44 variedades locales de Etiopía, así como 26 de CIP, 22 americanas y 17 europeas y clones avanzados de mejoramiento. Los datos de los marcadores revelaron que la mayoría de las variedades locales fueron duplicadas; entre las 44 variedades probadas, se observaron solamente 15 genotipos únicos. El componente principal y el dendrograma de unión de vecinos mostraron que el germoplasma americano, europeo y del CIP de tres diferentes grupos, con variedades viejas de Etiopía, se traslapaban con los europeos, sugiriendo que las variedades viejas locales son de descendencia europea. Las variedades locales en general se separaron en dos distintos grupos, lo que sugiere que por lo menos dos introducciones distintas hicieron que surgieran las variedades locales actuales en Etiopía. El germoplasma etíope conserva niveles comparables de diversidad genética respecto al americano, europeo y del CIP, y pudiera suministrar la base para un programa nacional de mejoramiento de papa.

Keywords SNP chip $\cdot$ Solanum tuberosum

\section{Introduction}

Potato (Solanum tuberosum L.) is the world's third most important food crop in overall production after rice and wheat, and is a food security crop (Devaux et al. 2014) in some countries, including Ethiopia. The past few decades have seen a dramatic increase in potato production and demand in many developing countries (FAO 2014). In Ethiopia, potato production area has increased more than fivefold from 30,000 ha 
during the 1970s (Kidane Mariam 1979) to more than 169,000 ha today (CSA 2014). The climate of the Ethiopian highlands is well-suited for potato production. That, combined with the need for a crop that can be harvested in August and September to meet seasonal food shortages, are two reasons why potato production has expanded so dramatically.

Although the International Potato Center (CIP) has worked with Ethiopian partners to introduce many new cultivars over the past three decades, most Ethiopian farmers still grow older local cultivars (Labarta et al. 2012; Kolech et al. 2015). The origin of these cultivars is not well understood, although it is clear that local cultivars differ considerably from each other in terms of adaptation to the numerous ecological zones of the country, as well as for many important traits (e.g., storability, drought tolerance, marketability, suitability for making stew) (Abebe et al. 2013; Kolech et al. 2015). Seventy to $90 \%$ of Ethiopian farmers report growing at least two local cultivars each year. Nationally, about $77 \%$ of Ethiopian potato land is planted to local cultivars each year (Kolech et al. 2015).

Kidane Mariam (1979) suggested that Ethiopian local cultivars may have originated from a small number of introductions and reported that local cultivars were low yielding. Because of the perception of poor yield, local cultivars have received relatively little attention from the research community. Instead, cultivar improvement has centered on evaluating clones developed by outside sources, primarily CIP. Using this approach, the Ethiopian potato cultivar development program has released at least 29 potato cultivars since 1987 (MOA 2013). In addition, three Dutch cultivars have been registered in Ethiopia by a private company, SolaGrow. Nonetheless, only $23 \%$ of the production area is allocated to new cultivars (Kolech et al. 2015), and only a few of the new cultivars have been adopted (Woldegiorgis 2013).

Potato has been cultivated in Ethiopia since its introduction by a German botanist, Wilhelm Schimper, in about 1858 (Pankhurst 1964). The next known introduction was over 100 years later, in 1971-72, when several Dutch cultivars were tested in the country (Kidane Mariam 1979). There may have been introductions between 1858 and 1971, e.g., by missionaries, but we know of no documentation supporting this. After 1972, several authors reported the introduction of additional cultivars (Yilma 1987; Lemaga et al. 1994; Woldegiorgis et al. 2001). In 1981, 27 commercial cultivars were introduced from the Netherlands and tested under Ethiopian conditions (Lemaga et al. 1994). From these introductions only one cultivar, 'Krolisa', was released in Ethiopia, under the name 'Wechecha' (Kolech et al. 1998). According to Woldegiorgis et al. (2001), drought in 1985 resulted in the importation of more than 2340 tons of seed of European potato cultivars, some of which could have been saved for seed. Because Ethiopia lacks a cultivar registration system for local cultivars, and does not have an advanced seed certification system, it is very difficult, if not impossible, to trace back the origins of current local cultivars through historical records alone.
The first step in crop improvement in a developing country should be a full assessment of the local material (Williams et al. 1991). Similarly, Ortiz (2001) argued that including locally adapted potato germplasm in crossing would help ensure that the resulting cultivars could be produced in a sustainable and environmentally-friendly manner. Molecular markers are playing an increasingly important role in the management and utilization of plant genetic resources (Karp 2002). The recent development of a single nucleotide polymorphism (SNP) chip for potato has made it possible to assess genetic variation in a dosage-sensitive manner at thousands of loci simultaneously (Hirsch et al. 2013). Using the potato 8303 SNP chip, we evaluated genetic variation in local cultivars collected from the two major potato production zones of Ethiopia (Northwest and South) as well as from cultivars developed in America and Europe, and cultivars developed by CIP. Our objectives were to: 1) assess the extent to which cultivars in Ethiopia are known by different names (not uncommon in countries without a strong, formalized seed system); 2) examine the genetic diversity of Ethiopian potatoes; and 3) assess the relationship between Ethiopian cultivars and cultivars/advanced clones developed in other parts of the world (CIP, America and Europe).

\section{Material and Methods}

\section{Plant Materials}

Forty-four local cultivars were collected from Northwest (Amhara region) and Southern (Oromia and SNNPR) Ethiopia (Fig. 1) during 2012 and 2013. Ten to twentyfive tubers of each local cultivar were collected from either markets or farmers' fields, and their names recorded based on the knowledge of growers, traders and/or marketers. Details of the collections are shown in Table 1. Passport data including cultivar characteristics and estimated time of introduction were also collected at the time of collection but these data were not comprehensive. Each cultivar was planted in a screen house at the Adet Agricultural Research Center for morphological observation and genetic fingerprinting. At the same time, DNA was isolated from 31 CIP genotypes (17 improved' cultivars and 14 advanced clones) from research fields at the Adet and Holetta Agricultural Research Centers. The improved cultivars represent those introduced into Ethiopia from CIP research sites in Peru and Kenya at different times, which were subsequently tested and ultimately officially released for production in Ethiopia. The CIP advanced clones represent new introductions from CIP for evaluation as possible new cultivars. Details of the CIP materials are shown in Table 2. 


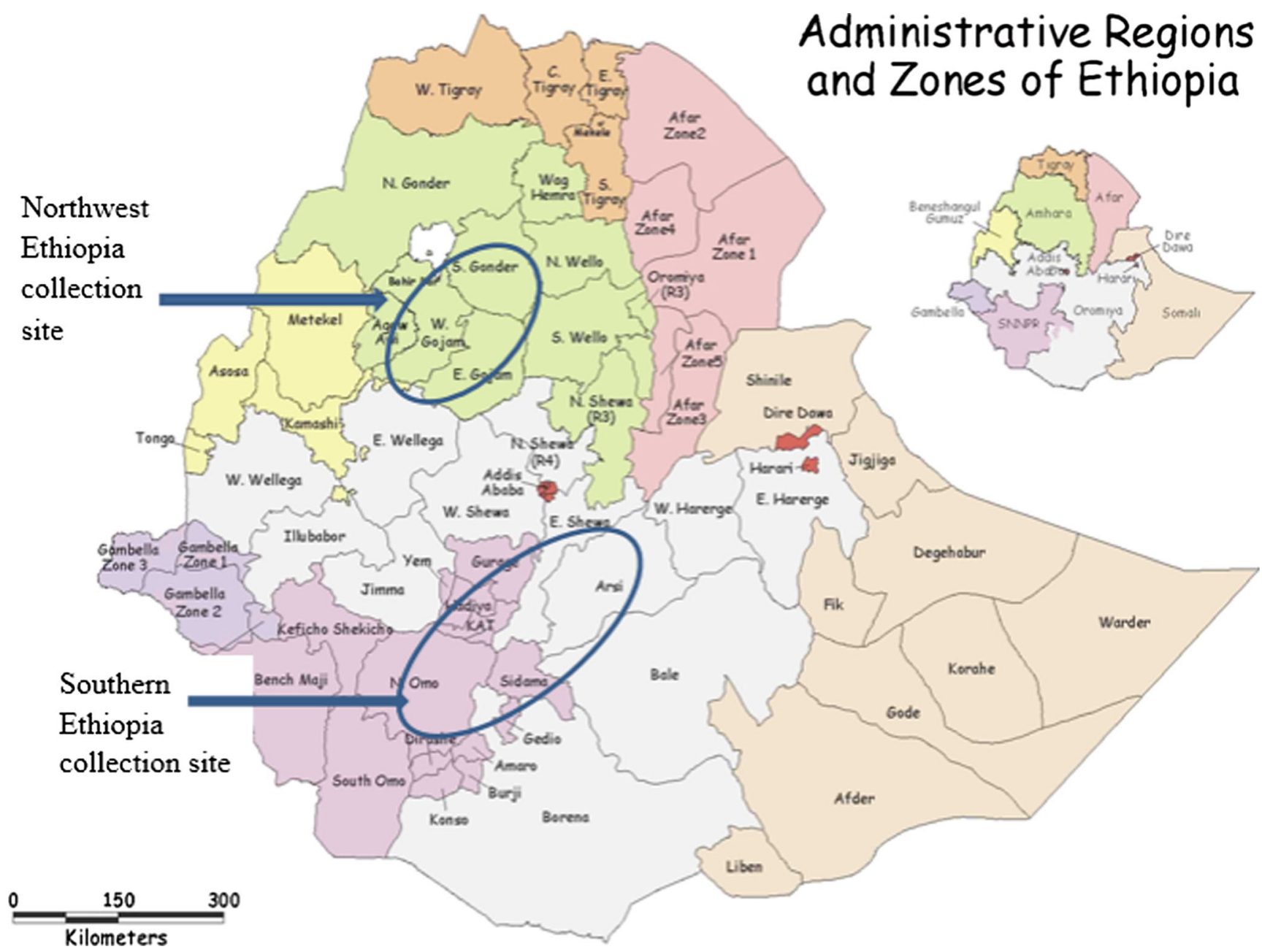

Fig. 1 Local cultivar collection sites

SNP data of 22 widely grown American cultivars were generated previously (Hirsch et al. 2013). SNPs from European cultivars were collected using the same SNP chip as for the Ethiopian, American and CIP germplasm. The American and European cultivars evaluated are summarized in Table 2, and represent several market classes (chipping, French fries and table), as well as old and newer cultivars.

\section{Morphological Assessment}

The vines, flowers and tubers of local cultivars were characterized using descriptors for cultivated potato (Huaman et al. 1977) to complement the results of DNA analysis. For leaf and stem characteristics, stem color, shape of stem cross section, abaxial and adaxial leaf pubescence, leaf dissection, leaf size, leaf color, growth habit and branching habit were recorded. Flower characteristics measured included flower color, degree of flowering, and tendency to premature flower abscission. Tuber characteristics recorded after harvest include tuber skin color, tuber flesh color, tuber skin texture, secondary tuber color, tuber shape, and storability.

\section{DNA Extraction and SNP Genotyping}

DNA was extracted from two young leaves of each cultivar/ advanced clone (from screen house plants for local cultivars, and from field grown plants of CIP advanced clones) using the CTAB method of Mace et al. (2003). The quality of each DNA sample was checked by agarose gel electrophoresis and a Nano Drop spectrophotometer (Thermo Fisher Scientific, USA). Later, the DNA was sent to Cornell University and clarified using a QIAGEN DNeasy Plant Minikit (QIAGEN, Germantown, MD). The DNA was then sent to Michigan State University and genotyped at 8303 SNP loci using the potato Illumina Infinium array developed by the SolCAP project (Hirsch et al. 2013). Loci with low-signal intensity or that displayed no polymorphism, or that did not cluster well into discrete dosage categories were filtered out. Of the 8303 markers genotyped, data from 3696 were retained for evaluation of potato diversity. 
Table 1 List of Ethiopian potato cultivars sampled along with their collection sites

\begin{tabular}{|c|c|c|c|c|}
\hline Code & Common name & Collection site & Regional state & Identical to code \\
\hline 01 & Nech Abeba & West Wondo & South & 15 \\
\hline 02 & Durame Shule & West Wondo & ‘ & 12 \\
\hline 03 & Key Abeba & Shasho & ‘ & 14,17 \\
\hline 04 & Fayzer & Azo Tala & ‘ & 13 \\
\hline 05 & Nech & Azo Tala & ‘ & 08,20 \\
\hline 06 & Feleke & Chencha & ‘ & 07 \\
\hline 07 & Akime & Genko & ‘ & 06 \\
\hline 08 & Gedigala & Aderagot & ‘ & 05 \\
\hline 09 & Asmera & Damote Gale & ‘ & 11 \\
\hline 10 & Achire & Damote Gale & ‘ & - \\
\hline 11 & Durame & Damote Gale & ‘ & 09 \\
\hline 12 & Agazer & Shashemene & Oromia & 02 \\
\hline 13 & Bulle & Kofele & ‘ & 04 \\
\hline 14 & Key Shule & Shashemene & ‘ & 03,17 \\
\hline 15 & Nech Abeba & Shashemene & ‘ & 01 \\
\hline 16 & Key & Woyra & ‘ & $19,23,32,33,35,40,43$ \\
\hline 17 & Achire China & Kofele & ‘ & 03,14 \\
\hline 18 & Holland & Limu Belebel & ‘ & - \\
\hline 19 & Key & Bekoji & ‘ & $16,23,32,33,35,40,43$ \\
\hline 20 & Gojjame & Bekoji & ‘ & 05,08 \\
\hline 21 & Abalo & Yilmana & Amhara & $26,30,38,39,42$ \\
\hline 22 & Samune & Yilmana & ‘ & - \\
\hline 23 & Siquare & Yilmana & ‘ & $19,32,33,35,40,43$ \\
\hline 24 & Rejim Siquare & Yilmana & ‘ & 28,44 \\
\hline 25 & Abadamu & Yilmana & ‘ & 31 \\
\hline 26 & Abalo & Quarit & ‘ & $21,30,38,39,42$ \\
\hline 27 & Samune & Quarit & ‘ & $23,28,44$ \\
\hline 28 & Abateneh & Quarit & ‘ & 24,44 \\
\hline 29 & Ayito & Quarit & ‘ & 34 \\
\hline 30 & Abadamu & Quarit & ‘ & $21,26,38,39,42$ \\
\hline 31 & Abalo large & Quarit & ‘ & 25 \\
\hline 32 & Siquare & Quarit & ‘ & $19,23,33,35,40,43$ \\
\hline 33 & Achire & Quarit & ‘ & $19,23,33,35,40,43$ \\
\hline 34 & Kuchibiye & Sinan & ‘ & 29 \\
\hline 35 & Demie & Sinan & ‘ & $19,23,32,33,40,43$ \\
\hline 36 & Agere & Sinan & ‘ & 37 \\
\hline 37 & Enat Beguaro & Sinan & ‘ & 36 \\
\hline 38 & Abadamu & Sinan & & $21,26,30,39,42$ \\
\hline 39 & Tikure & Laigaint & ‘ & $21,26,30,38,42$ \\
\hline 40 & Key & Laigaint & ‘ & $19,23,32,33,3543$ \\
\hline 41 & Komitate & Injibara & ‘ & Sisay, a new cultivar \\
\hline 42 & Abalo & Injibara & ‘ & $21,26,30,38,39$ \\
\hline 43 & Mirit & Injibara & ‘ & $19,23,32,33,40$ \\
\hline 44 & Abathunegn & Sekela & ‘ & 24,28 \\
\hline
\end{tabular}

\section{Genotypic Data Analysis}

To study the genetic relationship of Ethiopian local cultivars to each other, as well as to cultivars/advanced clones from North America, Europe and CIP, a neighbor joining analysis was performed. The SplitsTree4 program version 4.13.1 was used to construct an unweighted pair group method with arithmetic mean (UPGMA)-based 
Table 2 List of CIP potato cultivars and advanced clones, as well as European and North American cultivars

\begin{tabular}{|c|c|c|c|}
\hline \multicolumn{2}{|l|}{ CIP } & \multirow[t]{2}{*}{ European } & \multirow[t]{2}{*}{ American } \\
\hline New cultivars & Advanced clones & & \\
\hline Menagesha (CIP-374080.5 & CIP-3960004.337 & Bintje & Andover \\
\hline Gera (KP-90134.2 & CIP-396038.107 & Spunta & Atlantic \\
\hline Challa (CIP-387412.2 & CIP-396027.205 & Asterix & Kennebec \\
\hline CIP-378501.16 & CIP-396043.226 & Favorita & Pike \\
\hline Awash $^{\mathrm{a}}(\mathrm{CIP}-378501.3)$ & CIP-395112.36 & Pentland Dell & Snowden \\
\hline Gorebella (CIP-382173.12 & CIP-391046.14 & Torridon & Lamoka \\
\hline Zengena (CIP-380479.6 & CIP-396004.225 & Innovator & Lenape \\
\hline Shenkolla (KP-90134.5 & CIP-393382.44 & Hindenburg & Chieftain \\
\hline Hundie (KP-90147.8 & CIP-393385.39 & Korona & NorDonna \\
\hline Bulle (CIP-387224.25 & CIP-396036.201 & Bzura & Eramosa \\
\hline Belete (CIP-393371.58) & CIP-395111.19 & Kuba & Superior \\
\hline Gabisa (CIP-387096.11 & CIP-393280.57 & Greta & Garnet Chile \\
\hline Araarsa (KP-90138.12 & CIP-393280.82 & Kerr's Pink & Irish Cobbler \\
\hline Guasa $^{\mathrm{a}}$ (CIP-384321.9) & CIP-396034.103 & Stirling & Eva \\
\hline Jalene (CIP-384321.19 & - & Sieglinde & Yukon Gold \\
\hline Gudene (CIP-386423.13) & - & Kondor & Sebago \\
\hline Dagim (CIP-395096.2) & - & Picasso & Katahdin \\
\hline- & - & - & Russet Burbank \\
\hline- & - & - & Russet Norkotah \\
\hline- & - & - & Western Russet \\
\hline- & - & - & RioGrande Russet \\
\hline- & - & - & Dark Red Norland \\
\hline
\end{tabular}

${ }^{\mathrm{a}}$ These cultivars were not included in the final clustering and genetic diversity analysis; names in parentheses are CIP code names for those cultivars. tree (Huson and Bryant 2006). Archaeopteryx version 0.9901 beta was then used to generate the tree image (Han and Zmasek 2009). Principal component analysis was conducted using JMP software (JMP 2012). The SNP data were first converted into numeric data $(\mathrm{AAAA}=-1, \mathrm{AAAB}=-0.5, \mathrm{AABB}=0, \mathrm{ABBB}=0.5$, $\mathrm{BBBB}=1$ ), then the principal component analysis was computed from the correlation matrix.

Genetic diversity among Ethiopian cultivars and between Ethiopian cultivars and germplasm from America, Europe and CIP was calculated using a custom R script based on the method described by Thrall and Young (2000). After minor allele frequencies for each locus were calculated for a subgroup of all cultivars and advanced clones combined, expected heterozygosity values (chromosome inheritance model) for each allele were calculated as

$$
\mathrm{H}=2 * \mathrm{p}^{3} * \mathrm{q}+4 * \mathrm{p}^{2} * \mathrm{q}^{2}+2 * \mathrm{q}^{3} \mathrm{p}
$$

Where $\mathrm{p}$ is the major allele frequency, $\mathrm{q}$ is minor allele frequency, $p+q=1$, the $A A A B$ and $A B B B$ genotypes are given a heterozygosity weight of 0.5 , and $\mathrm{AABB}$ is given a heterozygosity weight of 0.667 (Bever and Felber 1992). Expected heterozygosities for each subgroup $\left(\mathrm{H}_{\mathrm{S}}\right)$, and for all cultivars/advanced clones combined $\left(\mathrm{H}_{\mathrm{T}}\right)$ were calculated by averaging expected heterozygosities across all loci. Genetic differentiation of each group relative to all potato cultivars/advanced clones $\left(\mathrm{F}_{\mathrm{ST}}\right)$ was calculated as $\left.\mathrm{F}_{\mathrm{ST}}=\left(\mathrm{H}_{\mathrm{T}}-\mathrm{H}_{\mathrm{S}}\right) / \mathrm{H}_{\mathrm{T}}\right)$. Expected heterozygosity of each of the 3696 loci for each of the four groups were arranged in four columns in Excel and exported to JMP software (JMP 2012). Then, $t$ statistics were computed to test whether expected heterozygosity between groups was significantly different. Genetic differentiation between groups was arranged in the same way as expected heterozygosity, and t statistics similarly computed to test pairwise differentiation between groups. Expected heterozygosity, rather than observed heterozygosity, was used in this study as the former provides a framework for comparing genetic variation across groups, while the latter is better suited for detecting deviations from Hardy-Weinberg equilibrium. 


\section{Results}

\section{Identifying Cultivars by Morphological and Molecular Characterization}

In the course of growing out samples of cultivars collected from farmers' fields and markets, we observed that seven of the 44 samples were cultivar mixtures, where the phenotypes of some plants in a sample were strikingly different from other plants in the same sample. Morphological descriptions collected from farmers or marketers during the course of collecting were used to identify which of the two cultivars in a mixture would be subjected to further analyses.

We also detected mislabeling in cultivars handled by Ethiopian research centers. SNP analysis revealed that samples of the new cultivars 'Awash' and 'Gabisa' were identical, as were samples of 'Tolcha' (UK-80.3) and 'Shenkolla'. We used CIP potato catalogue and Ethiopian cultivar registry booklets to determine which cultivars these actually were ('Gabisa' and 'Shenkolla', respectively).

Our genotyping and morphological evaluations further revealed that 'Sisay', a CIP-bred cultivar, is one of the most widely grown cultivars in Yilmana (Northwest Ethiopia). When we collected this cultivar, there was no reason to believe it was anything other than a local cultivar, because it was not documented in the Ethiopian potato cultivar registry. We later noticed that CIP had recently released a cultivar by the name of 'Sisay' in Ethiopia (Acquisition and Distribution Unit 2008). The morphological features used to define 'Sisay' in the CIP catalog are identical to the morphological characteristics of the cultivar we had collected.

\section{Duplications within Ethiopian Collections}

Farmers name potato cultivars based on varietal characteristics that they readily perceive. Most Ethiopian local cultivar names are based on descriptors such as texture, flower and tuber color, taste, or productivity. However, after conducting morphological and SNP comparisons, we found that some cultivar are known by many different names across the country. Of the 44 samples of local cultivars, described with 33 unique names, we found only 15 unique genotypes. The names and known synonyms of each of the 15 unique genotypes are shown in Table 3. For instance, a widely grown cultivar in Northwest Ethiopia (West Amhara region) is known as 'Deme' or 'Demas' in Sinan, as 'Ater Abeba' and 'Siquare' in Yilmana, Quarit and some districts of the Awi zone, as 'Mirt' in Banja, and as 'Key Dinch' in Laigaint. The same cultivar is known as 'Key' in Bekoji and 'Woyra' in Southern Ethiopia. A cultivar with the same morphology as 'Siquare' is known as 'Abateneh' at Sekela, and 'Rejim Siquare' at Yilmana and Quarit. A surprising observation was that two improved cultivars, 'Jalene' and 'Guasa', were found to be identical by both SNP and morphological analyses. These two cultivars have long been considered siblings in Ethiopia, as it is known that both originated from the same CIP cross (Table 2). 'Jalene' was released by the Holeta Agricultural Research Center while 'Guasa' was released by the Adet Agricultural Research Center. It is remarkable that these two cultivars were not known to be identical until now. Similarly, two CIP advanced clones, CIP393382.44 and CIP-393385.39 were found to be identical.

These duplications have misled previous authors, who reported the names of these cultivars as if they represented different genotypes (Woldegiorgis et al. 2008; Tesfaye et al. 2008; Yazie et al. 2009; Labarta et al. 2012). For example, Tesfaye et al. (2008) reported 'Demie', 'Siquare' and 'Key Abeba' as if these names represented different cultivars but our DNA and morphological analysis showed that they are identical. Adding to the confusion, the Hawassa Agricultural Research Center released a new cultivar in 2005 known as 'Bulle' (MOA 2006) which, unfortunately, was already the name of a widely grown local cultivar.

In a few cases we observed distinct genotypes known by the same name. Traders at Hawassa refer to the distinct genotypes of 'Durame' and 'Agazer' as 'Durame', whereas all farmers in Shashemene (who supply the Hawassa markets) correctly identify these as different cultivars with different names. Similarly, consumers and traders in the city of Bahir Dar used the name 'Key Dinch' for both 'Siquare' and 'Abateneh'.

It is important for future cultivar identification, research and breeding if each cultivar is known by one, and only one, unique name. Our proposed unique names for local cultivars that are currently known by one or more duplicate names are shown in Table 3; in all cases, we propose the name that is most widely used at present. To differentiate the local 'Bulle' cultivar from the new 'Bulle' cultivar, which are genotypically and morphologically distinct, we propose renaming the local cultivar as 'Bulle Local'.

\section{Genetic Relationships among Ethiopian Local Cultivars and Relationship to Cultivars from CIP, America and Europe}

After removing duplicate genotypes, cluster analysis was performed again. Data from 3696 polymorphic SNPs were analyzed to construct the neighbor-joining dendrogram shown in Fig. 2. With a few exceptions, potato cultivars and advanced clones from America $(n=22)$, Europe $(n=17)$ and CIP $(n=26)$ separated into three distinct branches. Ethiopian cultivars ( $n=15)$ localized to the European and CIP branches; none clustered with American cultivars. The oldest cultivars from northwest Ethiopia ('Enat Beguaro', 'Abalo' and 'Samune') 
Table 3 Proposed names for Ethiopian local cultivars, along with known duplicate names, cultivar characteristics and areas of adaptation

\begin{tabular}{|c|c|c|c|}
\hline $\begin{array}{l}\text { Proposed cultivar } \\
\text { name (where grown) }\end{array}$ & $\begin{array}{l}\text { Known duplicate names } \\
\text { (where grown) }\end{array}$ & Areas of adaptation & Cultivar characteristics \\
\hline Abalo (Northwest Ethiopia) & Bayle Lakew (Sinan) & Cool highlands of Northwest Ethiopia & $\begin{array}{l}\text { Tall plants, white flowers, many fruit, long } \\
\text { dormancy, late maturing, oblong tubers, } \\
\text { tolerance to cold temperature, thick leaves }\end{array}$ \\
\hline Abadamu (Yilmana) & Abalo Large (Quarit) & Cool highlands of Northwest Ethiopia & $\begin{array}{l}\text { Large umbrella-shaped leaves, sets many fruit, } \\
\text { long dormancy, shallow eyes and low dry } \\
\text { matter content }\end{array}$ \\
\hline Enat Beguaro (Sinan) & $\begin{array}{l}\text { Agere (Quarit and Yilmana), Amore } \\
\text { (Quarit) }\end{array}$ & Sinan (Northwest Ethiopia) & $\begin{array}{l}\text { Short stature, dense foliage, many stems per } \\
\text { plant, does not flower, small oval-to-oblong } \\
\text { tubers }\end{array}$ \\
\hline Siquare (Yilmana) & $\begin{array}{l}\text { Key Dinch (Laigaint), Mirit Zer } \\
\text { (Banja), Demas (Quarit)), Deme } \\
\text { (Sinan) Ater Abeba (Yilmana), Key } \\
\text { (Bekoji and Woyira) }\end{array}$ & $\begin{array}{l}\text { Northwest Ethiopia and some areas } \\
\text { of South Ethiopia }\end{array}$ & $\begin{array}{l}\text { Dense foliage, red flowers, many fruit, small } \\
\text { leaves, early maturing, round tubers with } \\
\text { red skin, medium-deep eyes, susceptible to } \\
\text { cold temperature }\end{array}$ \\
\hline Samune & Samune (Quarit and Banja) & Banja district of Awi Zone & $\begin{array}{l}\text { White flowers, flat and long tubers, long } \\
\text { dormancy }\end{array}$ \\
\hline Abateneh (Sinan and Quarit) & Siquare Long (Yilmana) & $\begin{array}{l}\text { Sekela and Quarit districts in Northwest } \\
\text { Ethiopia }\end{array}$ & $\begin{array}{l}\text { Tall plants, red flowers, late maturing, round } \\
\text { tubers with smooth red skin, deep eyes, } \\
\text { medium storability in storage but poor } \\
\text { storability in soil }\end{array}$ \\
\hline Kuchibiye (Sinan) & Ayito (Quarit) & West and East Gojjam (northwest Ethiopia) & $\begin{array}{l}\text { Tall plants, pigmented leaf vein, purple tubers, } \\
\text { white flowers }\end{array}$ \\
\hline Feleke (Chencha) & Akime (Genko) & South Ethiopia & $\begin{array}{l}\text { Tall plants, very late maturing, red flowers, } \\
\text { round tubers with medium deep eyes }\end{array}$ \\
\hline Durame (Damote Galle) & Asmera (Damote Dale) & Wolaita zone & Long dormancy, round to oval tubers \\
\hline Agazer (Shashemene) & Durame Shule (Wondo) & East Arsi and South Ethiopia & $\begin{array}{l}\text { Early maturing, small oval tubers, good shelf } \\
\text { life, white flowers }\end{array}$ \\
\hline Key Shule (Shashemene) & $\begin{array}{l}\text { Key Abeba (Shasho), Achire China } \\
\text { (Kofele) }\end{array}$ & East Arsi & $\begin{array}{l}\text { Light pink flowers, short stature, oval tubers, } \\
\text { large and shiny leaves, early maturing, } \\
\text { short dormancy }\end{array}$ \\
\hline Bulle Local & Bulle (Kofele), Fayzer (Azotella) & South Ethiopia & $\begin{array}{l}\text { Tall plants, purple stems and leaf lamina, } \\
\text { profuse white flowers, round purple tubers }\end{array}$ \\
\hline Gedigala (Damote Galle) & Nech (Azo-Tella) & South Ethiopia & $\begin{array}{l}\text { Large leaves, stem cross section angular and } \\
\text { green with pink discoloration, semi-erect, } \\
\text { round to oval tubers, deep eyes, yellow tuber } \\
\text { flesh }\end{array}$ \\
\hline Nech Abeba (Shashemene) & Nech (Wondo) & Shashemene and surrounding areas & $\begin{array}{l}\text { Tall plants, profuse white flowers, round and } \\
\text { white tubers, short dormancy }\end{array}$ \\
\hline Holland & Holland (Limu Belbel) & South Ethiopia & Tall plants, oval tubers, light pink flowers \\
\hline
\end{tabular}

and Southern Ethiopia ('Durame') all grouped within the European branch. The southern Ethiopian local cultivar 'Key Shule', the widely grown local cultivar 'Siquare', and the less widely grown local cultivars 'Feleke' and 'Gedigala' group in a separate sub-cluster of the European branch.

Two cultivars from Northwest Ethiopia ('Kuchibiye' and 'Abadamu') and major cultivars from southern Ethiopia ('Holland', 'Nech Abeba', 'Agazer' and 'Bulle') group together with several of the CIP cultivars and advanced clones evaluated. 'Kuchibiye' and 'Bulle' are also similar morphologically, both being known by their pink tuber color and pigmented leaf veins. 'Abateneh' (from northwest Ethiopia) is the only Ethiopian cultivar that grouped in a distinct subcluster of CIP cultivars and advanced clones.

Genetic relationships were further assessed using principal components analysis, which showed that American, European and CIP-bred cultivars and advanced clones group into three distinct clusters with relatively little overlap (Fig. 3). Most local cultivars of northwest Ethiopia cluster with the European group while the dominant cultivars of Southern Ethiopia cluster with the CIP group.

\section{Heterozygosity in Ethiopian Potatoes Compared to American, European and CIP Cultivars and Advanced Clones}

3696 polymorphic SNP markers were used to calculate expected heterozygosity $\left(\mathrm{H}_{\mathrm{S}}\right.$ and $\left.\mathrm{H}_{\mathrm{T}}\right)$. There are small but statistically significant differences in heterozygosity between Ethiopian, American, European and CIP cultivar groups (Table 4). Even though the Ethiopian cultivar group did not contain any unique SNP alleles (Fig. 4), higher heterozygosity was observed in the Ethiopian group compared to the CIP group. The American group is the most heterozygous, and had more unique alleles than any other group, possibly because the SNPs on the chip were chosen for their polymorphism in American cultivars. The CIP group exhibited the lowest heterozygosity of all four groups.

\section{Genetic Differentiation}

Genetic differentiation was analyzed for each of the four cultivar groups compared to all potato cultivars and advanced clones combined, as well as between groups, as shown in Table 4 . 


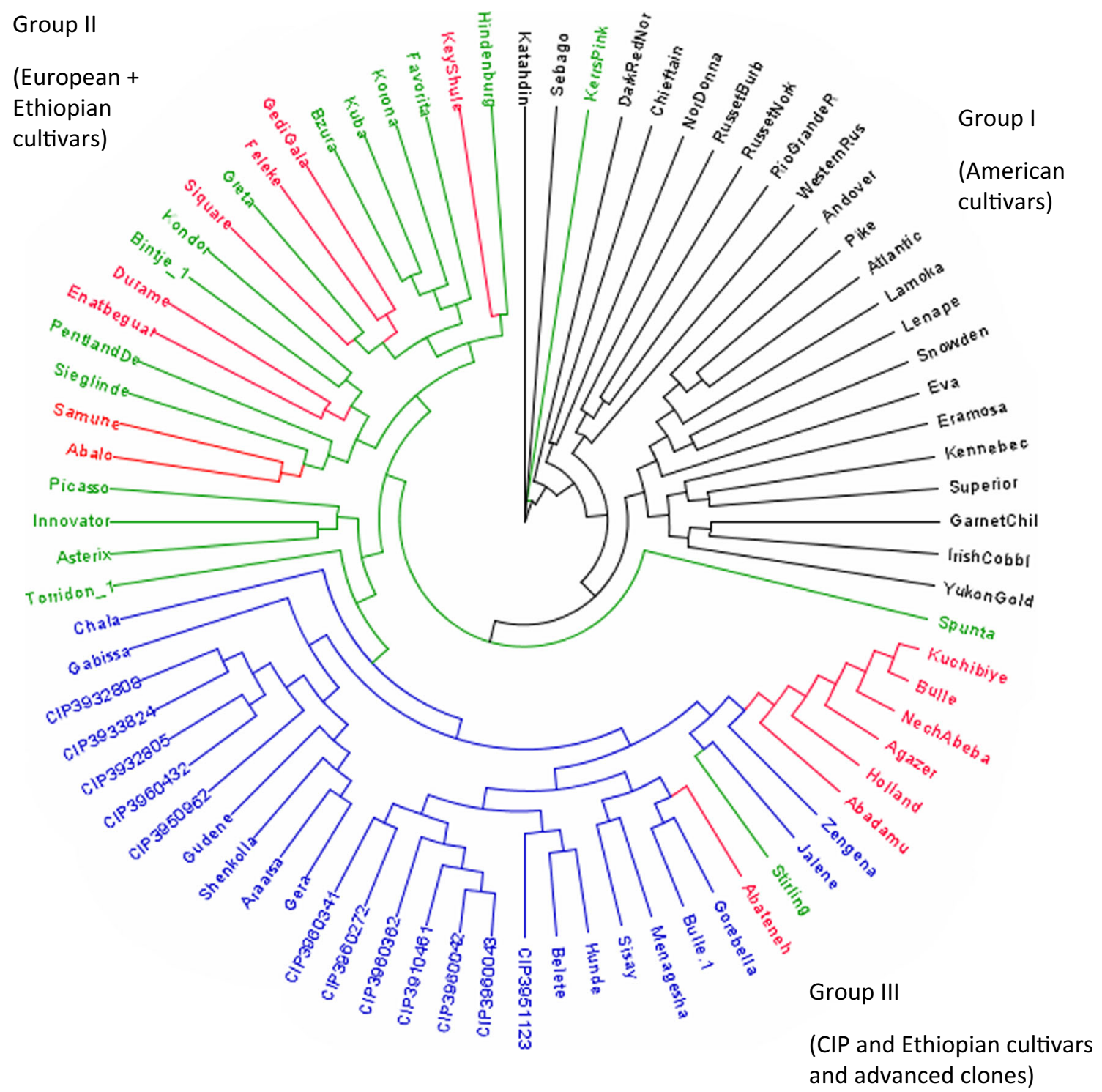

Fig. 2 Clustering of cultivars and advanced clones using neighborjoining analysis of 3696 SNP markers. American cultivars are shown in black, European cultivars are shown in green, CIP (International Potato

Center) cultivars and advanced clones are shown in blue, and local Ethiopian cultivars are shown in red

Pairwise genetic differentiation between groups showed that each group is statistically different from every other group, but the magnitude of each pairwise difference was small. The Ethiopian cultivar subgroup is more closely related to CIP and European germplasm than to American cultivars.

\section{Discussion}

\section{Causes of Duplications among Ethiopian Cultivar Collections}

Of the 44 local potato cultivars evaluated in Ethiopia, we found only 15 distinct genotypes. Most of these 15 genotypes are known by different names in different parts of the country.
The high frequency of duplications likely exists because the dominant seed system in Ethiopia is informal (Gildemacher et al. 2009; Hirpa et al. 2010): seed tubers are produced and disseminated without any regulations. The movement of seed tubers is common in Ethiopia (Samberg et al. 2013; Kolech et al. 2015). Agents for seed movement can be individuals, nongovernmental and governmental organizations, and farmer's cooperatives. During the Derg regime (1974-1991), farmer's cooperatives played a major role in moving planting material.

Farmers in different districts name potato cultivars based on characteristics that they perceive. Most cultivar names are based on descriptors related to texture, color, taste, productivity and time to maturity. For instance, one widely grown cultivar in northwest Ethiopia ('Siquare' from Table 1) is currently known by many different names, where each name represents an 


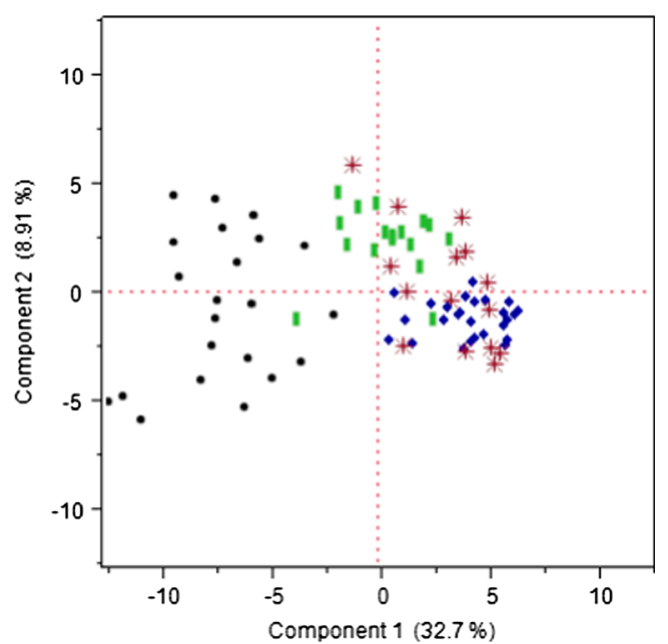

Fig. 3 Principal components of the simple matching coefficient matrix, calculated from 80 potato cultivars genotyped with 3696 polymorphic SNP markers. American cultivars are represented by black dots, European cultivars are represented by green rectangles, CIP cultivars and advanced clones are represented by blue diamonds, and local Ethiopian cultivars are represented by red stars. The percent variation explained by the first and second components is shown in parentheses

attribute of this cultivar. 'Siquare' means sugary taste in Yilmana, Quarit and some districts of the Awi zone; 'Deme' or 'Demas' means dark red tuber color in the Sinan district; 'Ater Abeba' means that the flower color is similar to the flower color of field peas; 'Mirt' means best in the Banja district; and 'Key Dinch' means red colored potato in the Laigaint district. Similarly, 'Abateneh' means "father" in Sekela while in Yilmana this cultivar is known as 'Rejim Siquare' because it is taller than 'Siquare'. The name 'Ayito' means colored like a mouse because tubers are blue-black in color, while this cultivar is called 'Kuchbiye' in Sinana, which means late maturing.

The genotyping results reported here can serve as a first step in developing officially recognized names for local cultivars. Our proposed names for each unique genotype, summarized in Table 3, can be taken as a starting point, since we know of no reliable historical records to determine the original name for each cultivar.

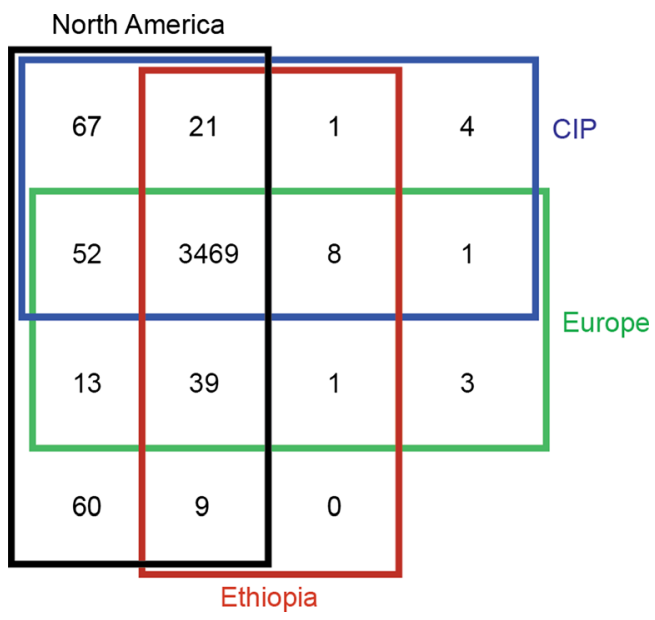

Fig. 4 Venn diagram illustrating how SNPs are distributed among Ethiopian, North American, European and CIP cultivars and advanced clones. Individuals of each group were genotyped with 3696 polymorphic SNP markers. The Ethiopian, North American, European and CIP cultivars and advanced clones are represented by red, black, green, and blue rectangles, respectively

\section{Origin and Relationships among Ethiopian Cultivars}

Although potato has been grown in Ethiopia for over 150 years, the origin of current local cultivars is not known. Based on genetic relationships gleaned from molecular marker data (Figs. 2, and 3), it appears likely that most local cultivars in the northwest originated in Europe. Several authors have reported that many cultivars have been introduced over the past 40 years from European countries as well as the International Potato Center (Peru) (Kidane Mariam 1979; Yilma 1987; Lemaga et al. 1994). Some of these introductions may have become the local cultivars grown today. Alternatively, or in addition, it is possible that Ethiopian farmers selected local cultivars from naturally occurring crosses. The long growing season of the Belg and Belmehr seasons in the cool agroecological zones of Ethiopia favors the development of mature true potato seeds (TPS). Any seed that germinates can, in principle, become a new cultivar if it meets farmer's needs. Many Andean potato cultivars are believed to

Table 4 Mean SNP diversity for 3696 SNP markers

\begin{tabular}{|c|c|c|c|c|c|c|c|c|}
\hline \multirow[t]{2}{*}{ Group } & \multirow{2}{*}{$\begin{array}{l}\text { Number of } \\
\text { genotypes }\end{array}$} & \multirow{2}{*}{$\begin{array}{l}\text { Mean minor } \\
\text { allele frequency }\end{array}$} & \multirow{2}{*}{$\begin{array}{l}\text { Expected } \\
\text { heterozygosity }^{\mathrm{a}}\end{array}$} & \multirow{2}{*}{$\begin{array}{l}\text { Differentiation compared to all cultivars } \\
\left.\text { and advanced clones combined ( } \mathrm{F}_{\mathrm{ST}}\right)\end{array}$} & \multicolumn{4}{|c|}{ Pairwise genetic differentiation $\left(\mathrm{F}_{\mathrm{ST}}\right)$} \\
\hline & & & & & American & European & CIP & Ethiopian \\
\hline American & 22 & 0.263 & $0.350 \mathrm{a}$ & 0 & - & $0.0707 *$ & $0.1314 *$ & $0.1097^{*}$ \\
\hline European & 17 & 0.238 & $0.326 \mathrm{~b}$ & 0.0191 & & - & $0.0607 *$ & $0.0391 *$ \\
\hline CIP & 27 & 0.223 & $0.306 \mathrm{~d}$ & 0.0798 & & & - & $0.0217^{*}$ \\
\hline Ethiopia & 15 & 0.228 & $0.313 \mathrm{c}$ & 0.0582 & & & & - \\
\hline All genotypes & 81 & 0.244 & 0.331 & - & & & & \\
\hline
\end{tabular}

${ }^{\mathrm{a}}$ Levels not connected by the same letters are significantly different at $\mathrm{P}<0.05$ at $\mathrm{t}=1.96$

*The values are significantly different at $\mathrm{P}<0.001$ 
have been produced by farmer selection from naturally occurring variation (Bradshaw et al. 2006).

According to Ethiopian farmers, some local cultivars have been grown for more than 40 years. These old cultivars include 'Abalo', 'Samune', 'Enat Beguaro' and 'Durame'. All four of these cultivars are most closely related to the European cultivars tested. Some recent cultivars, such as 'Siquare', are also most closely related to European cultivars. According to farmers, 'Siquare', the most commonly grown cultivar in northwest Ethiopia, has been grown for the last 25 years. Morphologically, 'Siquare' looks like an andigena type, as it has small leaves and flowers profusely. Despite its similarity to European cultivars, it is not possible to confidently conclude that 'Siquare' originated from Europe, as CIP also uses European cultivars as parents.

Unlike northern cultivars, the predominant southern cultivars ('Nech Abeba', 'Agazer', 'Bulle' and 'Holland') are most closely related to germplasm developed by CIP. According to farmers, these cultivars are also not as old as most of the cultivars in the Northwest. Thus, the major cultivars of the south are likely of different origin than the Northwest. One or more of these cultivars may represent direct adoption of advanced clones introduced by CIP. Cultivar introduction from CIP began 32 years ago (Lemaga et al. 1994). According to Kidane Mariam (1979), the first CIP cultivars were tested in 1976 in central, Southern and Eastern Ethiopia (Holetta, Nazreth, Alemaya, Endiber, Chencha, Areka and Kulumsa).

Within Ethiopia it is believed that potato cultivars introduced into the country during the past 23 years can all be traced back to their initial introduction, since a National Seed Industry Policy was issued by the government in 1992 to regulate seed import and export (Bishaw et al. 2008). Even so, there are some cases, like 'Abateneh', a local Ethiopian cultivar that has been grown for the last 10 years, where it is impossible to find information about its origin. Molecular genetic characterization shows that 'Abateneh' is related to 'Gorebella' and 'Bulle' (new cultivars that originated at CIP). It may be that tubers were taken from research fields during cultivar testing; advanced CIP clones are tested in research plots in many parts of Ethiopia. It is also possible, but less likely, that 'Abateneh' was selected from TPS by farmers, where one or both parents were CIP cultivars.

\section{Divergence and Population Differentiation}

It has been suggested that maximum heterozygosity leads to maximum heterosis and thus high yield in potato (Mendoza and Haynes 1974). Increasing the heterozygosity of Ethiopian local cultivars and widening their genetic base are both likely to be important breeding activities as new Ethiopian cultivars are developed that possess desired combinations of abiotic and biotic stress tolerances and high yield. An unexpected result of this study is that Ethiopian cultivars are more heterozygous than the CIP clones tested. Our naïve expectation was that since CIP cultivars and advanced clones have genes from many different species, they would contain many unique alleles, and be more heterozygous. The reduced heterozygosity compared to Ethiopian cutlivars, as well as lower numbers of unique alleles, compared to North America, may be due entirely, or in part, to ascertainment bias, as the SNPs evaluated were pre-selected for being informative in US germplasm. As Hamilton et al. (2011) noted, novel alleles in CIP sources derived from wild species may not have been detected because SNPs for the infinium array were derived exclusively from cultivated potato. Indeed, Vos et al. (2015) have demonstrated that relatively few of the SNPs evaluated by the SolCAP 8303 array represent SNPs introduced into potato after 1945, i.e., recent introgressions. When SSR markers were used to compare CIP germplasm with that from Kenya and Europe, the CIP germplasm was found to have the most within-group diversity (Lung'aho et al. 2011).

It is abundantly clear from the heterozygosity analyses, and evaluation of private and shared SNPs, that Ethiopian cultivars harbor considerable genetic diversity; this in turn negates the belief that Ethiopian potato cultivars are derived from a markedly narrower genetic base than American, European or CIP cultivars and advanced clones.

\section{Implications for Future Potato Breeding and Conservation}

Breeders require sufficient genetic variation when developing new cultivars adapted to changing environmental conditions and emerging pests and diseases. Such cultivars are especially important for Ethiopian farmers, where low input agriculture is the norm, and weather variability has increased in recent years. This study is the first to characterize Ethiopian potato genetic resources in relation to cultivars from the International Potato Center, America and Europe, using molecular genetic and morphological methods. We have found that current Ethiopian cultivars harbor considerable genetic variation, comparable to that found in CIP, European and American germplasm. American germplasm differs the most from Ethiopian material, suggesting that crossing with American cultivars could help broaden the genetic base in Ethiopia. Moreover, establishing a consistent name for each unique genotype is undoubtedly the first step in registering these cultivars for future development of the crop and for conservation of these genotypes.

Acknowledgments This work was supported by Borlaug LEAP USAID grant number 016258. We thank the Holetta Biotechnology Research Institute, Ethiopia, for their support in extracting DNA in their facility. We are highly indebted to Alemu Worku for his help in collecting of Ethiopian cultivars and Shuping Cheng and Sisay Kidane for their support in DNA extraction. The help of Jason Wallace and Hannah De Jong for data analysis is also appreciated. 


\section{References}

Abebe, G.K., J. Bijman, S. Pascucci, and S. Omta. 2013. Adoption of improved potato cultivars in Ethiopia: the role of agricultural knowledge and innovation system and smallholder farmers' quality assessment. Agricultural Systems 122: 22-32.

Acquisition and Distribution Unit. 2008. Catalog of potato cultivars. Peru: International Potato Center (CIP), Lima.

Bever, J.D., and F. Felber. 1992. The theoretical population genetics of autopolyploidy. In Oxford surveys in evolutionary biology, ed. J. Antonovics, and D. Futuyma, 185-217. New York: Oxford University Press.

Bishaw, Z., Y. Sahlu, and B. Simane. 2008. The status of Ethiopian Seed Industry. In Farmers, Seeds and cultivars: supporting informal seed supply in Ethiopia, ed. M.H. Thijssen, Z. Bishaw, A. Beshir, and W.S. De Boef. Wageningen International: Wageningen 348 p.

Bradshaw, J.E., G.J. Bryan, and G. Ramsay. 2006. Genetic resources (including wild and cultivated Solanum species) and progress in their utilization in potato breeding. Potato Research 49(1): 49-65.

CSA (Central Statistical Agency). 2014. Agricultural sample survey report on area and production (private peasant holdings in Meher season). Addis Ababa, Ethiopia: Statistical Bulletin.

Devaux, A., P. Kromann, and O. Ortiz. 2014. Potatoes for sustainable global food security. Potato Research. doi:10.1007/s11540-014-9265-1.

FAO. 2014. FAO statistical databases FAOSTAT. http://faostat3.fao.org/ Accessed 15 Jun 2015

Gildemacher, P., P. Demo, I. Barker, W. Kaguongo, W. Gebremedhin, W.W. Wagoire, M. Wakahiu, C. Leeuwis, and P.C. Struik. 2009. A description of seed potato systems in Kenya, Uganda and Ethiopia. American Journal of Potato Research 86: 373-382.

Hamilton, J.P., C.N. Hansey, B.R. Whitty, K. Stoffel, A.N. Massa, A. Van Deynze, W.S. De Jong, D.S. Douches, and C.R. Buell. 2011. Single nucleotide polymorphism discovery in elite north American potato germplasm. BMC Genomics 12: 302. doi:10.1186/1471-2164-12-302.

Han M.V. and C. M. Zmasek. 2009. BMC Bioinformatics. 10: 356

Hirpa, A., M.P.M. Meuwissen, A. Tesfaye, W.J.M. Lommen, A.O. Lansink, A. Tsegaye, and P.C. Struick. 2010. Analysis of seed potato systems in Ethiopia. American Journal of Potato Research 87: 537-552.

Hirsch, C.N., C.D. Hirsch, K. Felcher, J. Coombs, D. Zarka, A. Van Deynze, W. De Jong, R.E. Veilleux, S. Jansky, P. Bethke, D.S. Douches, and C.R. Buell. 2013. Retrospective view of north American potato (Solanum tuberosum L.) breeding in the 20th and 21st centuries. G3: Genes. Genomes, Genetics 3: 1003-1013. doi:10.1534/g3.113.005595.

Huaman, Z., T. Williams, W. Salhuana, and L. Vincent. 1977. Descriptors for the cultivated potato. FAO: International Board for Plant Genetic Resources.

Huson, D., and D. Bryant. 2006. Application of phylogenetic networks in evolutionary studies. Molecular Biology and Evolution 23(2): 254-267.

JMP, 2012. Version JMP PRO 10.0.2. SAS Institute INC., Cary, NY

Karp, A. 2002. The new genetic era: will it help us in managing genetic diversity? In Managing plant genetic diversity, ed. J.M.M. Engels, V.R. Rao, A.H.D. Brown, and M.T. Jackson, 43-56. Rome: International Plant Genetic Resources Institute.

Kidane Mariam, H. 1979. Preliminary assessment of the responses of potato genotypes in the eastern, southern and central regions of Ethiopia. Eth. J. Agr. Sci. 1(1): 41-47.

Kolech, S.A., B. Tuku and G. Woldegiorgis. 1998. Potato Research in North Shewa. In Agricultural Research and Technology Transfer Attempt and Achievements in Northern Ethiopia, eds. Beyene Seboka and Aberra Deressa. Proceedings of the Fourth Technology Generation, Transfer and Gap Analysis Workshop. 18-21 March 1997, Bahir Dar, Ethiopia

Kolech, S.A., D. Halseth, W. De Jong, K. Perry, D. Wolfe, F.M. Tiruneh, and S. Schulz. 2015. Potato cultivar diversity, determinants and implications for potato breeding strategy in Ethiopia. American Journal of Potato Research 92: 551-566.

Labarta, R., S. Wambungu, C. Yirga, J. Mugabo, J. Nsabimana, C. Mulwa, S. Schulz, C. Lorochelle, J. Alwang, R. Andrad, and Y. Yigezu. 2012. Report on objective 2 of the diffusion and impacts of improved cultivars in Africa (DIIVA) project. Kenya: International Potato Center (CIP), Nairobi.

Lemaga, B., G. Woldegiorgsi, T. Jalleta, B. Tuku and Y. Hiskias. 1994. Potato improvement research. Eds. Edward Herath and Lemma Dessalegn (eds.). Proceedings of the Second National Horticultural Workshop of Ethiopia. 1-3 Dec. 1992. Addis Ababa, Ethiopia.

Lung'aho, C., G.N. Chemining'wa, Y. Fu, S. Shibairo, M.J. Hutchinson, and H.J. Paniagua. 2011. Genetic diversity of Kenyan potato Germplasm revealed by simple sequence repeat markers. American Journal of Potato Research 88: 424-434.

Mace, E.S., H.K. Buhariwalla, and H.J. Crouch. 2003. A high throughput DNA extraction protocol for tropical molecular breeding programs. Plant Molecular Biology Reporter 21: 459a-459 h.

Mendoza, H.A., and F.L. Haynes. 1974. Genetic relationship among potato cultivars grown in the United States. Hortscience 9: 328-330.

MOA (Ministry of Agriculture). 2006. Cultivar registry booklet. Ethiopia: Addis Ababa.

MOA (Ministry of Agriculture). 2013. Cultivar registry booklet. Ethiopia: Addis Ababa.

Ortiz, R. 2001. The state of the use of potato genetic diversity. Broadening the genetic base of crop production. Eds. H.D. Cooper, C. Spillane and T. Hodgkin. IPGRI/FAO

Pankhurst, R. 1964. Notes on the history of Ethiopian agriculture. Observer 7: 210-240.

Samberg, L.H., C. Shennan, and E. Zavaleta. 2013. Farmer seed exchange and crop diversity in a changing agricultural landscape in the southern highlands of Ethiopia. Human Ecology 41: 477-485.

Tesfaye, A., K. Bedane, C. Yirga, and G. Woldegiorgis. 2008. Socioeconomics and technology transfer. In In Root and tuber crops: The untapped resources, ed. W. Woldegiorgis, E. Gebre, and B. Lemaga. Addis Ababa: Ethiopian Institute of Agricultural Research.

Thrall, P.H., and A. Young. 2000. Autotet: a program for analysis of Autotetraploid genotypic data. The Journal of Heredity 91: 348-349.

Vos, P.G., J.G.A.M.L. Uitdewilligen, R.E. Voorrips, R.G.F. Visser, and H.J. van Eck. 2015. Development and analysis of a $20 \mathrm{~K} \mathrm{SNP}$ array for potato (Solanum tuberosum): an insight into the breeding history. Theoretical and Applied Genetics 128: 2387-2401.

Williams, C.N., J.O. Uzo, and W.T.H. Peregrine. 1991. Vegetable production in the tropics. Longman Scientific and Technical, Essex: Intermediate Tropical Agriculture Series.

Woldegiorgis, G. 2013. Potato cultivar development strategies and methodologies in Ethiopia. In seed potato tuber production and dissemination: experiences, challenges and prospects, eds. Woldegiorgis, G., S. Schulz and B. Berihun. Proceedings of the national workshop on seed potato tuber production and dissemination, 12-14 March 2012, Bahir Dar, Ethiopia.

Woldegiorgis, G., B. Kassa, E. Gebre, and A. Solomon. 2001. Country profile on potato production and utilization: Ethiopia. Ethiopian Agricultural Research Organization (EARO)

Woldegiorgis, G., E. Gebre, and B. Lemaga. 2008. Potato cultivar development. In In Root and tuber crops: The untapped resources, ed. W. Woldegiorgis, E. Gebre, and B. Lemaga. Addis Ababa, Ethiopia: Ethiopian Institute of Agricultural Research.

Yazie, C., T. Akal, T. Yalfal, and B. Baye. 2009. Characterization of potato production, marketing, and utilization in northwestern Amhara region, 41 pp. Adet Agricultural Research Center, Bahir Dar, Ethiopia: Ethiopia. Working paper.

Yilma, S. 1987. Review of potato research in Ethiopia. Eds. GodfreySam-Aggrey, W. and Bereke-Tsehai Tuku. Proceedings of first Ethiopian horticultural workshop. 20-22 Febraury, 1985, IAR, Addis Ababa, Ethiopia 